\title{
NOTES ON THE GROWTH AND BIOLOGY OF THE PRAWN SPIRONTOCARIS LILLFEBORGII (DANIELSSEN)
}

\author{
By R. B. Pike \\ The Marine Station, Millport
}

(Text-figs. I-3)

The biology of the spirontocarids appears to have attracted little attention and the larvae of the European species are imperfectly known.

While working on the prawn Pandalus bonnieri Caullery (Pike, I952), a considerable number of Spirontocaris lilljeborgii (Danielssen) were obtained on the same ground. This spirontocarid was infected by the bopyrid parasite, Phryxus abdominalis Kröyer. Collections of the prawn were made so that its biology, as well as that of the bopyrid, could be studied.

The author expresses indebtedness to colleagues at the Marine Station for assistance in preparing this paper, and to the Skipper and the crew of M.V. Calanus for their unfailing help in collecting material; to Miss E. R. Wallace for assisting in measuring specimens and to $\mathrm{Mr} \mathrm{J}$. N. Thomson for cutting and staining the sections.

\section{NOMENCLATURE}

Most European authors appear to have regarded Spirontocaris lilljeborgii as a distinct species from S. spinus (Sowerby). Appellöf (I906) does point out that although the two forms are usually distinct on the Scandinavian coast, intermediate forms have been obtained off Iceland. Kemp (I9I0) reviewed the situation while dealing with the Decapoda Natantia of Ireland and decided to call S. lilljeborgii a variety of S.spinus (S. spinus var. Lilljeborgi (Danielssen)). Holthuis (1947) has since reviewed the known species of Hippolytidae and has divided the genus Spirontocaris into further genera and given this variety specific status.

\section{COLlection of Material}

All the prawns were collected from the Cumbrae Deep ground in the Firth of Clyde, Scotland. This ground is situated off the Isle of Bute (National Grid Reference 26/II59-II62), at a depth of 70-90 m. The gear used for collecting the adults was an $8 \mathrm{ft}$ agassiz trawl having a net mesh of $\mathrm{I} \cdot 3 \mathrm{~cm}$ bar; this was found to retain prawns of above $7 \mathrm{~mm}$ carapace length. A one-metre modified agassiz, working $15 \mathrm{~cm}$ above the bottom and fitted with a mesh of I cm bar was used for younger prawns, and the same frame fitted with a one-metre 
stramin net was used for the collection of larvae and early post-larval forms. It was difficult to obtain adequate samples of all size groups in a single day, especially in the summer when the finer mesh nets had to be used for the smaller size groups. Frequently, 2 days were required to obtain an adequate sample, and in each case the earlier date for sampling is given; the second sample was obtained within 7 days of the first sample.

\section{MeAsurement of MAterial}

The standard measurement made was the 'length of the carapace', being the distance from the posterior margin of the eye socket to the dorsal posterior margin of the carapace. All early post-larval prawns were measured under the binocular microscope. The larger specimens were measured with fine draughtsman's calipers to the nearest I mm below and the data recorded in I mm groups.

\section{TABLE I}

\begin{tabular}{|c|c|c|c|c|}
\hline \multirow{2}{*}{$\begin{array}{l}\text { Carapace } \\
\text { length } \\
(\mathrm{mm})\end{array}$} & \multicolumn{3}{|c|}{ Total length (mm) } & \multirow{2}{*}{$\begin{array}{c}\text { No. } \\
\text { of eggs }\end{array}$} \\
\hline & Juveniles & Males & Females & \\
\hline I & - & - & - & - \\
\hline 2 & II $\cdot 8$ & - & - & - \\
\hline 3 & 13.6 & - & & \\
\hline 4 & - & $20 \cdot 0$ & 18.5 & - \\
\hline 5 & - & 23.5 & $22 \cdot 6$ & - \\
\hline 6 & - & $26 \cdot 2$ & $28 \cdot I$ & - \\
\hline 7 & - & $33 \cdot 8$ & $33 \cdot 5$ & 130 \\
\hline 8 & - & $36 \cdot 5$ & $37 \cdot \mathrm{I}$ & 164 \\
\hline 9 & - & $40 \cdot 3$ & $42 \cdot 3$ & 256 \\
\hline Io & - & - & $44 \cdot 9$ & 430 \\
\hline II & - & - & $48 \cdot 0$ & 516 \\
\hline I2 & - & - & $50 \cdot 2$ & 687 \\
\hline I3 & - & -- & $52 \cdot 3$ & 577 \\
\hline
\end{tabular}

At the same time total lengths, tip of rostrum to the tip of telson were measured, and the arithmetic mean taken for thirty specimens in each mm size group. These means are shown in Table $\mathrm{I}$, together with the mean number of newly laid eggs taken from five individuals in each available $\mathrm{mm}$ size group.

\section{GEOGRAPHICAL DistribUtion}

S. lilljeborgii is common in the Skagerrak and along the south and west coasts of Norway and has been recorded from Iceland (Stephensen, I939, p. I7). It is not recorded by the same author (1928, p. I3) for the Faeroes, and he is doubtful of his East Greenland record (I9I2, p. 5IO). This doubt is also shared by Heegaard (I94I, p. 42). Southward, S. lilljeborgii extends from the Irish Sea into the English Channel on the west and to the Norfolk coast on the east. S. spinus, however, is obtained from the Kattegat and along the whole west coast of Norway. It is recorded in small numbers from the Faeroes area, 
occurs on both the east and west coast of Iceland, and Greenland and as far north as Spitzbergen, Franz Joseph Land and Ellesmere Island. Its southern range is rather uncertain. According to Kemp (I9IO) only one rather atypical form was obtained from Irish waters. Dr N. S. Jones from the Marine Station, Port Erin, Isle of Man, informs me that he has obtained typical $S$. spinus from the Isle of Man, although $S$. lilljeborgii is more usually obtained. Thus in the British Isles the southern limit for $S$. spinus appears to be the Irish Sea on the west and possibly the Norfolk coast on the east.

\section{OCCURRENCE IN THE CLYDE}

As already stated, S. lilljeborgii occurs along with Pandalus bonnieri on a soft muddy substratum, inhabited by a community similar to that associated with P. borealis (Kröyer), as described by Hjort \& Ruud (1938). I have already detailed (Pike, I952) the main animal communities of this ground, and further details can be obtained from Allen (I953). Heegaard (I94I) notes that Spirontocaris spinus in Greenland prefers shallow water ( $12-50 \mathrm{~m}$ ) which is considerably shallower than its habitat in Spitzbergen. He suggests that this is possibly because Balanus porcatus da Costa, among which it hides, often occurs at Spitzbergen at greater depths than off the east coast of Greenland, and in both places Spirontocaris spinus is always found in association with this barnacle. As S. lilljeborgii does not occur in Greenland no similar observations were made for that species. Balanus porcatus is generally distributed within the Clyde, but does not occur in any number on the ground from which the specimens of Spirontocaris lilljeborgii have been obtained for this work, and no association with Balanus has been observed.

\section{Migration}

The adults were extremely difficult to obtain during May and June, that is, just after the breeding season when they are moulting. It is thought that an inshore migration takes place at this time and that the prawns do not return again in numbers to the deeper water until July.

\section{BREEDING}

In the Clyde the ovaries of the female prawns begin to mature at the end of August (Fig. I, A, I) when the developing eggs can be seen through the cuticle of the thorax as sage green masses. Egg-laying begins late in November, and is about complete in a month's time. Incubation of the eggs lasts 3 months.

My records for I95I show that on 2I November out of Ioo females of Spirontocaris lilljeborgii captured, two were in berry. By 7 January 1952, nine out of 200 females carried eggs showing eye pigmentation, and on I9 February four out of 205 females had hatched their eggs. These dates and figures suggest 

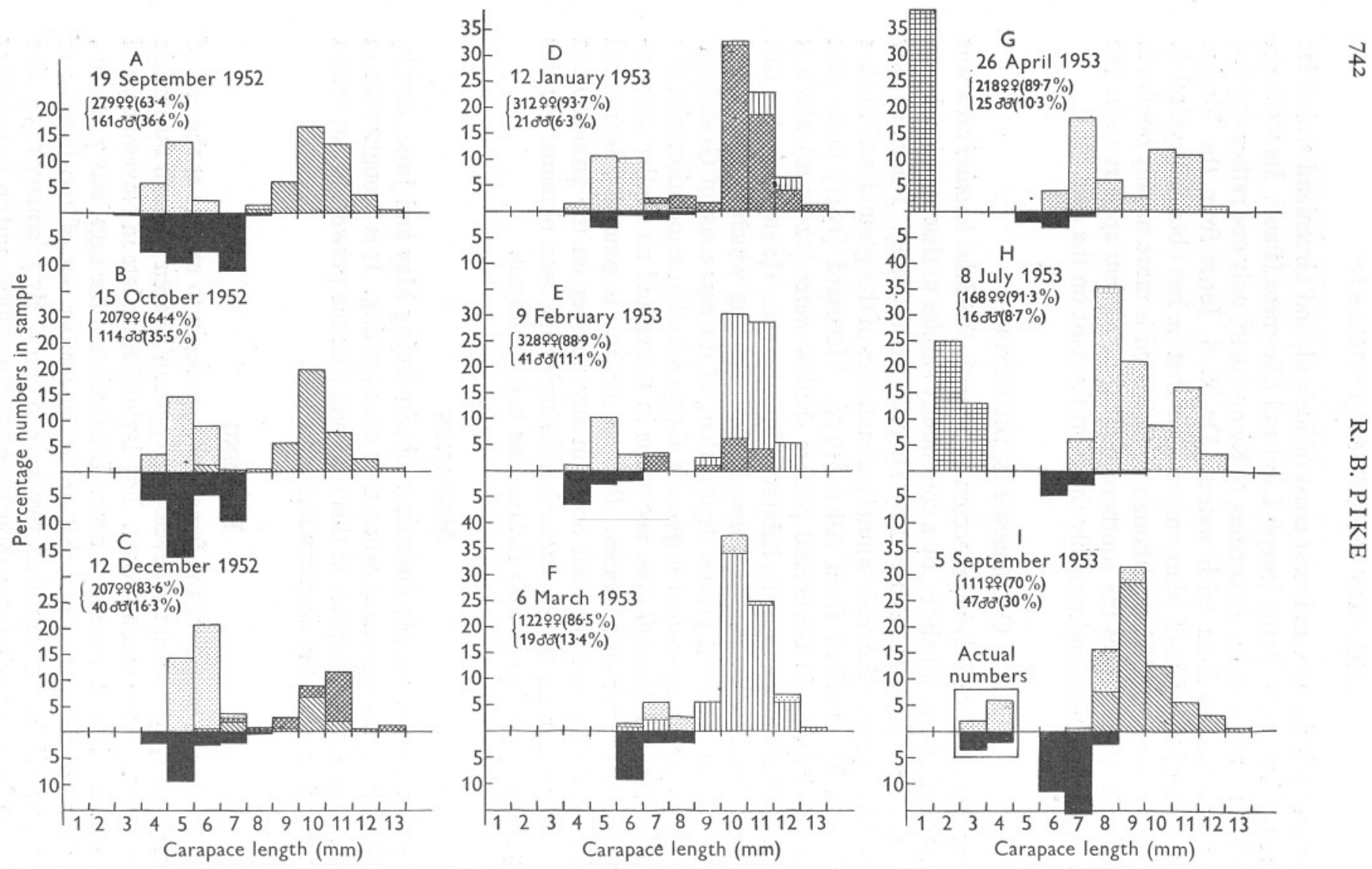

Fig. I. Breeding in Spirontocaris lilljeborgii.

males (below the datum line); females:

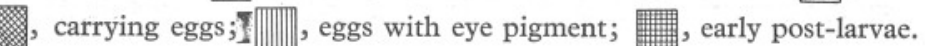


a total incubation period of 90 days. Egg-laying takes place about the time when the bottom sea temperature is highest (surface c. $9 \cdot 6^{\circ} \mathrm{C}$, bottom c. II $\cdot 5^{\circ} \mathrm{C}$ ), and hatching when it is lowest (surface $c .7 \cdot \mathrm{I}^{\circ} \mathrm{C}$, bottom $c .6 \cdot 5^{\circ} \mathrm{C}$ ). Eye pigmentation first becomes visible in the egg about the 47 th day after egg-laying. This is in keeping with the observations of Höglund (1942) who found that in Leander squilla (L.), kept in aquaria, eye pigmentation became visible half-way through egg development. The egg of $L$. squilla measures c. $0.45 \times 0.59 \mathrm{~mm}$ whereas that of Spirontocaris lilljeborgii is much larger, c. I. $0 \times 0.9 \mathrm{~mm}$. There appears, however, to be little difference either in the time taken for the eggs to develop or in the number of larval stages in these two prawns.

\section{RATE OF GROWTH}

The data obtained on growth are shown in graphic form in Figs. I and 2 and summarized in Table II. In preparing Fig. 2 the smallest and largest size has been shown for the age groups on the dates given in Fig. I and the lines that appeared to fit these drawn to show the general trend. The third year (II-group) is doubtful for both males and females, as the numbers are very small, and the difference in size might be explained by differential growths within the sexes during the second year. It did not seem advisable, on the data available, to work out the arithmetic means. The larvae of $S$. lilljeborgii were first recorded in 1953 on 5 March which is somewhat later than in I952. In both cases hatching appeared to be complete in about a month. Records show that the larvae take 4-5 weeks to pass through the larval stages and become bottom living. They grow quickly and reach a carapace length of from 2-3 mm by early July (Fig. I, H). Growth continues to be rapid until September when at a length of from 3 to $4 \mathrm{~mm}$ (Fig. I, I) the males can be distinguished from the females by the shape of their pleopods. At this time the ratio of males to females is approximately $\mathrm{I}: \mathrm{I}$.

By December the males have reached a carapace length of 4-6 cm and the females from 5 to $7 \mathrm{~cm}$. From now onwards the females grow much faster than the males, as will be seen in Table I and Fig. 2. During the winter months growth almost ceases for both sexes.

The usual life span for males appears to be 18 months, with a possible maximum of 30 months. With the females 24 months is the usual life span, although a few appear to live for 36 months.

The majority of the first-year males are sexually mature by the first autumn and probably fertilize the females, while only the largest of this o-group females are able to breed. (Fig. I, B, C). By December of their first year the largest of the o-group males have reached the same size as the smallest of the I-group males of the previous year. After the I-group male population has fertilized the females they appear to die (Fig. I, C). After December it was difficult to obtain any males and it was not until September 


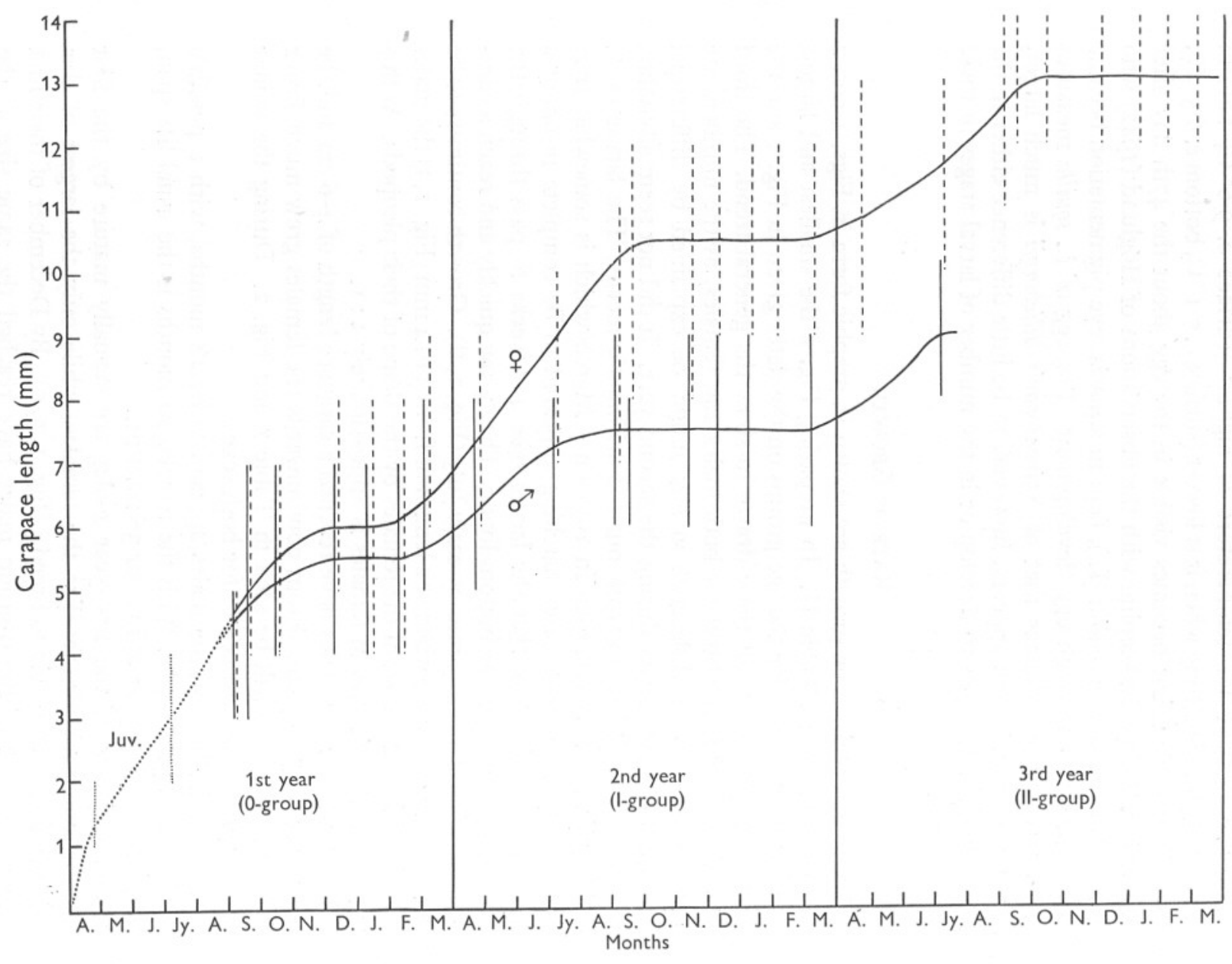

Fig. 2. Growth in Spirontocaris lilljeborgii. 
following that a number of males were again collected (Fig. I, I). This same scarcity of males has been noted over 2 years of sampling, and on no occasion has the collection of the second year (I-group) male population exceeded $30 \%$ of the total female population. I have pointed out above that the ratio of males to females for the o-group in September and October is roughly I : I, and although later sampling may be inadequate the ratio is probably less than

TABLE II. GROWTH OF SPIRONTOCARIS LILLFEBORGII

\begin{tabular}{|c|c|c|c|c|c|c|}
\hline \multirow[b]{2}{*}{$\begin{array}{c}\text { Month of } \\
\text { year }\end{array}$} & \multicolumn{2}{|c|}{ o-group } & \multicolumn{2}{|c|}{ I-group } & \multicolumn{2}{|c|}{ II-group } \\
\hline & $\begin{array}{c}\text { Age } \\
\text { (months) }\end{array}$ & $\begin{array}{c}\text { Carapace } \\
\text { length } \\
(\mathrm{mm})\end{array}$ & $\begin{array}{c}\text { Age } \\
\text { (months) }\end{array}$ & $\begin{array}{l}\text { Carapace } \\
\text { length } \\
(\mathrm{mm})\end{array}$ & $\begin{array}{c}\text { Age } \\
\text { (months) }\end{array}$ & $\begin{array}{l}\text { Carapace } \\
\text { length } \\
(\mathrm{mm})\end{array}$ \\
\hline 26 Apr. (G) & O-I & $I \cdot I-I \cdot 9$ & I2-I3 & $\begin{array}{l}5 \cdot I-7 \cdot 9 \\
6 \cdot I-8 \cdot 9\end{array}$ & $24-25$ & $\begin{array}{l}\text { Absent } \\
\text { क } 9 \cdot \mathrm{I}-\mathrm{I} 2 \cdot 9\end{array}$ \\
\hline 8 July (H) & $\mathrm{I}-4$ & $2 \cdot I-3 \cdot 9$ & I3-I6 & $\begin{array}{l}6 \cdot \mathrm{I}-7 \cdot 9 \\
07 \cdot \mathrm{I}-9 \cdot 9\end{array}$ & $25-28$ & 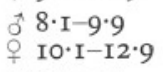 \\
\hline 5 Sept. (I) & $4-5$ & $3 \cdot I-4 \cdot 9$ & I6-I8 & $\begin{array}{l}\text { of } 6 \cdot \mathrm{I}-8 \cdot 9 \\
07 \cdot \mathrm{I}-10 \cdot 9\end{array}$ & $28-30$ & $\begin{array}{l}\text { Absent } \\
\text { of } \mathrm{II} \cdot \mathrm{I}-\mathrm{I} 3 \cdot 9\end{array}$ \\
\hline I9 Sept. (A) & $4-5$ & $\begin{array}{l}0 \begin{array}{l}3 \\
3\end{array} \text { I-6.9 } \\
+4 \cdot \mathrm{I}-6 \cdot 9\end{array}$ & I6-I8 & $\begin{array}{l}6 \cdot \mathrm{I}-8 \cdot 9 \\
\circ 8 \cdot \mathrm{I}-\mathrm{II} \cdot 9\end{array}$ & IO-I8 & $\begin{array}{l}\text { Absent } \\
\text { of } 12 \cdot 1-13.9\end{array}$ \\
\hline I5 Oct. (B) & $6-7$ & $\begin{array}{l}0.1 \cdot I-6 \cdot 9 \\
04 \cdot I-6 \cdot 9\end{array}$ & I8-I9 & $\begin{array}{l}6 \cdot I-7 \cdot 9 \\
8 \cdot 1-11 \cdot 9\end{array}$ & $30-3 I$ & $\begin{array}{ll} & \text { Absent } \\
0 & 12 \cdot 1-13.9\end{array}$ \\
\hline I2 Dec. (c) & 7-9 & $\begin{array}{l}8 \cdot 1-6 \cdot 9 \\
+5 \cdot 1-7 \cdot 9\end{array}$ & I9-2I & $\begin{array}{l}6 \cdot \mathrm{I}-8 \cdot 9 \\
+9 \cdot \mathrm{I}-\mathrm{I} \mathrm{I} \cdot 9\end{array}$ & $3 I-33$ & $\begin{array}{l}\text { Absent } \\
\text { I } 2 \cdot \mathrm{I}-\mathrm{I} 3.9\end{array}$ \\
\hline I2 Jan. (D) & 9-IO & $\begin{array}{l}0 \cdot 1 \cdot 1-6 \cdot 9 \\
+4 \cdot I-7 \cdot 9\end{array}$ & $2 \mathrm{I}-22$ & $\begin{array}{l}6 \cdot \mathrm{I}-8 \cdot 9 \\
09 \cdot \mathrm{I}-\mathrm{I} \mathrm{I} \cdot 9\end{array}$ & $33-34$ & $\begin{array}{l}\text { of Absent } \\
\text { of } 12 . \mathrm{I}-\mathrm{I} 3.9\end{array}$ \\
\hline 9 Feb. (E) & IO-II & $\begin{array}{l}0.1 \cdot I-6 \cdot 9 \\
\circ 4 \cdot I-7 \cdot 9\end{array}$ & $22-23$ & $\begin{array}{l}\text { Absent } \\
+9 \cdot \mathrm{I}-\mathrm{II} \cdot 9\end{array}$ & $34-35$ & $\begin{array}{l}\text { of Absent } \\
+\mathrm{I} \cdot \mathbf{2} \cdot \mathrm{I}-\mathrm{I} 3 \cdot 9\end{array}$ \\
\hline 6 Mar. (F) & $\mathrm{II}-\mathrm{I} 2$ & $\begin{array}{l}5 \cdot I-7 \cdot 9 \\
0.1-8 \cdot 9\end{array}$ & $23-24$ & $\begin{array}{l}\text { of } 7 \cdot \mathrm{I}-8 \cdot 9 \\
+9 \cdot \mathrm{I}-\mathrm{II} \cdot 9\end{array}$ & $35-36$ & $\begin{array}{l}\text { of Absent } \\
\text { of } 12 \cdot 1-13.9\end{array}$ \\
\hline
\end{tabular}

I : 2. It looks therefore as though some of the males die in their first year after fertilizing the females. To try and find out if this was the true ratio of males for the I-group for September I953 (Fig. I, I) sampling was carried out over 3 days with the I-m agassiz using the I cm bar mesh, so that no small males should escape. By this means it was found that the ratio of males to females was just under $\mathrm{I}: 2$. Such a method of collecting was too slow for general use, and the fine mesh was used for not more than half the collecting time.

\section{Sex Changes}

No change over from the male sex to the female sex has been observed. To check this point dissections of both sexes have been made and serial sections cut. The vas deferens of the male is a very thick and tightly coiled tube, and if any protandry occurred one would expect some trace of the vas deferens to remain after the change in sex had taken place, but this was not seen. The male pleopods are quite distinctive and intermediate forms should be easily seen during the examination of the male appendages. Lastly, serial sections through the male testis showed no trace of oocytes in the testicular tissue. 


\section{SeCONDARY SEXUAL CHARACTERS}

Höglund (1942) has given details of the breeding-dress in some Swedish eucyphideans (Caridea), and has described and figured the Ist pair of female pleopods for $S$. lilljeborgii during the breeding season, and during the rest of

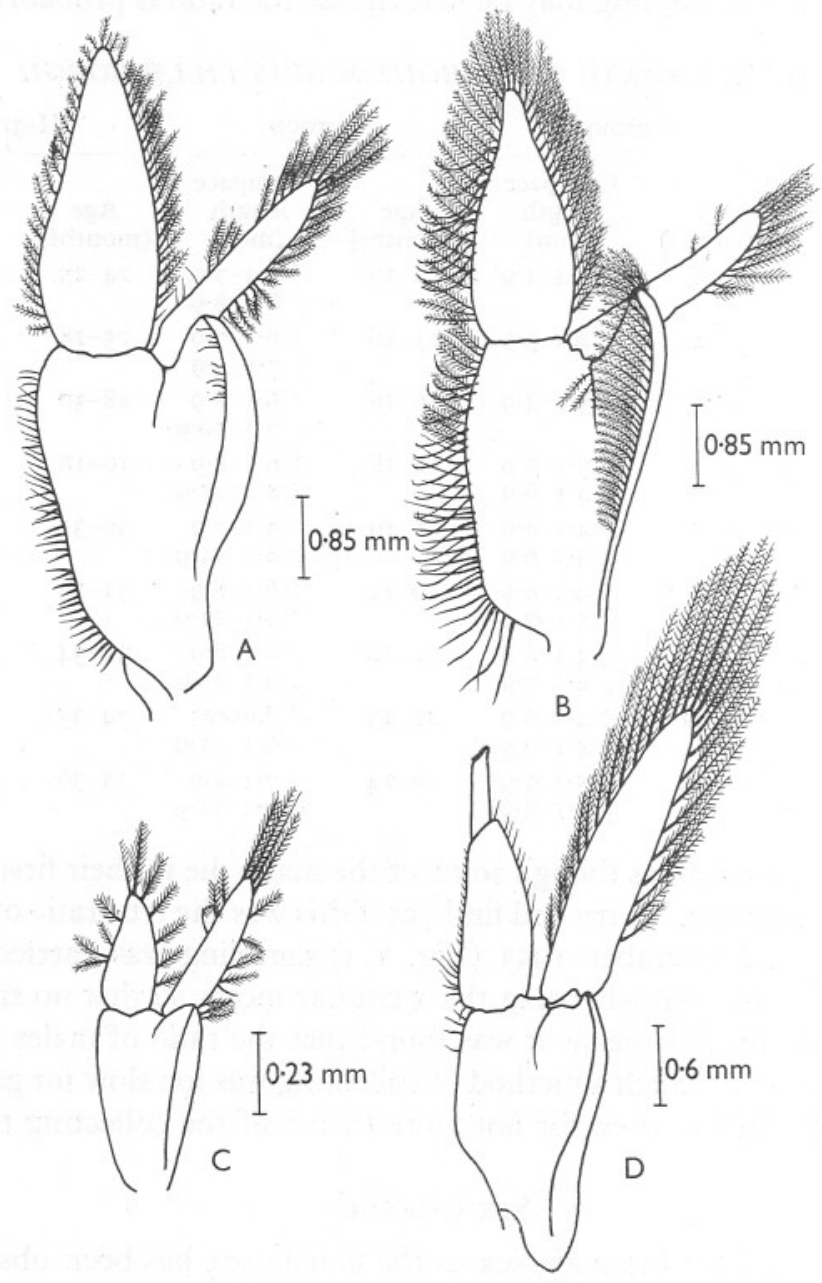

Fig. 3. The right pleopod of Spirontocaris lilljeborgii. A, female during the non-breeding season; B, female during the breeding season; $\mathrm{C}$, juvenile; $\mathrm{D}$, adult male.

the year. I agree entirely with his findings, and for completeness have made drawings of these, from my material, together with the undifferentiated pleopods of the juvenile and also those of the adult male prawn (Fig. 3). 


\section{SUMMARY}

Spirontocaris lilljeborgii is a dioecious species and no protandrous hermaphrodites have been seen.

The majority of males become sexually mature in the first year (7-9 months). Some of these may die after fertilizing the females and the majority die after fertilizing the females for a second year (I8 months old).

Only a small proportion of the females breed in their first year, all breed during their second year and a few appear to live for a third year.

A first-year female lays from I30 to I60 eggs, and the usual output of a second-year female is from 450 to 650 eggs.

Egg laying begins at the end of November and hatching is complete by the end of March.

The total incubation period is about 90 days. Eye pigmentation first appears at about half the incubation period ( 47 days).

Juveniles can be distinguished as males and females by the shape of their pleopods within 4-6 months of hatching.

\section{REFERENCES}

Allen, J. A., I953. Observations on the epifauna of the deep-water muds of the Clyde Sea Area, with special reference to Chlamys septemradiata (Müller). F. Anim. Ecol., Vol. 22, pp. 240-60.

Appellöf, A., I906. Die Dekapoden Crustacean. Meeresfauna, Bergen, Heft 2 and 3, pp. $133-233$.

Heegand, P. E., I94I. The Zoology of East Greenland. Decapod Crustaceans. Medd. Gronland, Bd. I2I, No. 6, 72 pp.

HJoRT, J. \& RuUd, J., I938. Deep-sea prawn fisheries and their problems. Hvalraid. Skrift., No. I7, I44 pp.

HöGLUND, H., I943. On the biology and larval development of Leander squilla (L.) forma typica de Man. Svenska hydrogr.-biol. Komm. Skr., N.S. (Biol.), Bd. 2, Nr. 6, 43 pp.

Holthuis, L. B., I947. The Decapoda of the Siboga Expedition. Pt. IX. The Hippolytidae and Rhynchocinatidae collected by the Siboga and Snellius expeditions, with remarks on other species. Siboga Exped., Monogr. 39, $a^{8}$, IOO pp.

Kemp, S., I9Io. The Decapoda Natantia of the coast of Ireland. Sci. Invest. Fish. Br. Ire., I908, No. I, $190 \mathrm{pp}$.

PIKe, R. B., I952. Notes on the growth and biology of the prawn Pandalus bonnieri Caullery. F. Mar. biol. Ass. U.K., Vol. 3I, pp. 259-67.

Stephensen, K., I912. Report on the Malocostraca, Pycnogonida and some Entomostraca collected by the Danmark Expedition to N.E. Greenland. Medd. Gronland, Bd. 45, No. II, p. 503-630.

- 1928. Marine Crustacea Decapoda. Zoology of the Faroes, Vol. 2, pt. I, 24 pp. Copenhagen.

- 1939. Crustacea Decapoda. The Zoology of Iceland, Vol. 3, pt. 25, 3I pp. Copenhagen. 